\title{
PENDEKATAN DAN MODEL PELAYANAN BK POLA 17 PLUS "JENIS PELAYANAN"
}

\author{
Azizah Permata Sari \\ Universitas Negeri Padang \\ Email : azizahpermatasari21@gmail.com
}

\begin{abstract}
The existence of guidance and counseling is needed so that students are able to know themselves, their environment in a positive and dynamic way. In order to be able to make decisions, practice and manifest oneself effectively and productively. The general pattern of counseling guidance includes all counseling guidance activities which include areas of guidance, types of services and counseling support activities. All counseling guidance activities in schools are aimed at all students (students) who are directly the responsibility of the supervisor or class teacher. Counseling guidance services in schools are carried out in a programmed, regular and sustainable manner.
\end{abstract}

Key words : Kind of service, guidance and counseling.

\begin{abstract}
Abstrak : Keberadaan bimbingan dan konseling sangat dibutuhkan agar siswa mampu mengenal dirinya sendiri, lingkungannya secara positif dan dinamis. Untuk dapat mengambil keputusan, berlatih dan mewujudkan diri secara efektif dan produktif. Pola umum bimbingan konseling meliputi semua kegiatan bimbingan konseling yang meliputi bidang bimbingan, jenis layanan dan kegiatan pendukung konseling. Semua kegiatan bimbingan konseling di sekolah ditujukan kepada semua siswa (siswa) yang menjadi tanggung jawab langsung pengawas atau guru kelas. Pelayanan bimbingan konseling di sekolah dilaksanakan secara terprogram, teratur dan berkelanjutan.
\end{abstract}

Kata kunci : Jenis layanan, bimbingan dan konseling. 


\section{Pendahuluan}

Bimbingan dan konseling pola 17 plus adalah progam bimbingan dan konseling atau pemberian bantuan kepada peserta didik melalui 6 bidang bimbingan, 9 layanan, dan 6 layanan pendukung yang sesuai dengan norma yang berlaku. Secara umum tujuan pola bimbingan dan konseling 17 plus adalah memberikan arah kerja atau sebagai acuan dan evaluasi kerja bagi guru bimbingan dan konseling/konselor, membantu peserta didik mengenal bakat, minat, dan kemampuannya, serta memilih dan menyesuaikan diri dengan kesempatan, pendidikan, dan merencanakan karier yang sesuai dengan tuntutan kerja.

\section{Layanan Bimbingan dan Konseling}

Layanan Bimbingan dan Konseling merupakan proses pemberian bantuan yang diberikan kepada siswa secara terus menerus agar tercapai kemandirian dalam pemahamandiri, sehingga siswa sanggup mengarahkan dirinya sesuai dengan tuntutan dan keadaan lingkungan sekolah, keluarga dan masyarakat. Dengan adanya bimbingan dan konselingdiharapkan dapat memberikan solusi bagi peserta didik disekolah. Agar peserta didik menjadi lebih baik dari segi perilakunya.

Layanan bimbingan dan konseling merupakan bagian integral dari pendidikan di Indonesia dalam upaya membantu siswa agar mencapai perkembangan yang optimal, sesuaidengan potensinya. Oleh karena itu, pelaksanaan bimbingan dan konseling disekolah menjadi tanggung jawab bersama antara personel sekolah, yaitu kepala sekolah, guru, konselor, dan pengawas.

\section{Jenis-Jenis Layanan Bimbingan dan Konseling}

Jenis layanan dan kegiatan dilakukan sebagai wujud penyelenggaraan pelayanan bimbingan dan konseling terhadap sasaran layanan (peserta didik). Layanan tersebut, diantaranya:

\section{a) Layanan Orientasi}

Menurut Prayitno (2004) orientasi berarti tatapan ke depan ke arah dan tentang sesuatu yang baru. Berdasarkan arti ini, layanan orientasi bisa bermakna suatu layanan terhadap siswa di sekolah yang berkenaan dengan tatapan ke depan ke arah dan tentang sesuatu yang baru. 
Layanan orientasi bertujuan untuk membantu individu agar mampu menyesuaikan diri terhadap lingkungan atau situasi yang baru. Secara lebih khusus, tujuan layanan orientasi berkenaan dengan fungsi-fungsi tertentu pelayanan bimbingan dan konseling. Dilihat dari fungsi pemahaman, layanan orientasi bertujuan untuk membantu individu agar memiliki pemahaman tentang berbagai hal yang penting dari suasana yang baru saja dijumpainya. Dilihat dari fungsi pencegahan, layanan orientasi bertujuan untuk membantu individu agar terhindar dari hal-hal negative yang dapat timbul apabila individu tidak memahami situasi atau lingkungan yang baru. Dilihat dari fungsi pengembangan, apabila individu mampu menyesuaikan diri secara baik dan mampu memanfaatkan secara konstruktif sumber-sumber yang ada pada situasi yang baru, maka individual akan dapat mengembangkan dan memelihara potensi dirinya.

Materi kegiatan layanan orientasi menyangkut :

1) Pengenalan lingkungan dan fasilitas sekolah.

2) Peraturan dan hak-hak serta kewajiban siswa.

3) Organisasi dan wadah-wadah yang dapat membantu dan meningkatkan hubungan sosial siswa.

4) Kurikulum dengan seluruh aspek-aspeknya.

5) Peranan pelayanan bimbingan konseling dalam membantu segala jenis masalah dan kesulitan siswa.

b) Layanan Informasi

Menurut Wingkel (1991) layanan informasi merupakan suatu layanan yang berupaya memenuhi kekurangan individu akan informasi yang mereka perlukan. Layanan informasi juga bermaknah usaha-usaha untuk membekali siswa dengan pengetahuan serta pemahaman tetang lingkungan hidupnya dan tentang proses perkembangan anak muda.

Layanan informasi bertujuan agar individu (siswa) mengetahui, menguasai informasi yang selanjutnya dimanfaatkan untuk keperluan hidupnya sehari-hari dan perkembangan dirinya.Selain itu, apabila merujuk kepada fungsi pemahaman, layanan informasi bertujuan agar individu memahami berbagai informasi dengan segala seluk beluknya. Penguasaan akan berbagai informasi dapat digunakan untuk mencegah timbulnya masalah, pemecahan suatu masalah, untuk memelihara dan mengembangkan potensi individu serta memungkinkan individu yang bersangkutan 
membuka diri dalam mengaktualisasikan hak-haknya. Layanan informasi juga bertujuan untuk pengembangan kemandirian.

Materi kegiatan layanan informasi menyangkut :

1) Usaha yang dapat dilakukan dalam mengenal bakat, minat, serta bentuk-bentuk penyaluran dan pengembangannya.

2) Tata tertib sekolah, cara bertingkah laku, tata krama, dan sopan santun.

3) Nilai-nilai sosial, adat istiadat, dan upaya yang berlaku dan berkembang dimasyarakat.

4) Mata pelajaran dan pembidangannya seperti program inti, program khusus, dan program tambahan.

5) Sistem penjurusan, kenaikan kelas, syarat-syarat mengikuti EBTA/EBTANAS.

6) Cara mempersiapkan diri dan belajar di sekolah.

c) Penempatan Penyaluran

Yaitu layanan bimbingan yang memungkinkan peserta didik memperoleh penempatan dan penyaluran yang tepat (misalnya penempatan/penyaluran didalam kelas, kelompok belajar, jurusan, atau program studi, magang, kegiatan kurikuler/ekstrakurikuler) sesuai dengan potensi, bakat, dan minat serta kondisi pribadinya.

Materi layanan penempatan dan penyaluran, antara lain :

1) Penempatan di dalam kelas, program studi atau jurusan dan pilihan ekstrakulikuler yang dapat menunjang pengembangan sikap, kebiasaan, kemampuan bakat dan minta.

2) Penempatan dan penyaluran ke dalam kelompok belajar, organisasi kesiswaan.

3) Penempatan dan penyaluran ke dalam program yang lebih luas, PMDK, UMPTN.

\section{d) Pengusaan Konten}

Yaitu layanan yang membantu peserta didik menguasai konten tertentu, terutama kompetensi dan atau kebiasaan yang berguna dalam kehidupan di sekolah, keluarga, dan masyarakat.

Materi umum layanan penguasaan konten ditujukan konseli dapat memiliki konten dalam: 
1) Ketrampilan teknik belajar.

2) Ketrampilan cara belajar yang efektif dan efisien.

3) Melatih kebiasaan belajar.

4) Melatih efisiensi waktu sehari-hari.

e) Konseling Perorangan

Yaitu layanan bimbingan dan konseling yang memungkinkan peserta didik mendapatkan layanan langsung secara tatap muka dengan guru pembimbing atau konselor dalam rangka pembahasan dan pengentasan permasalahannya. Tujuan dan fungsi layanan konseling perorangan dimaksudkan untuk memungkinkan siswa mendapatkan layanan langsung, tatap muka dengan konselor sekolah dalam rangka pembahasan dan pengentasan permasalahannya. Fungsi utama bimbingan yang didukung oleh layanan konseling perorangan ialah fungsi pengentasan.

Materi kegiatan layanan konseling perorangan meliputi:

1) Pemahaman sikap, kebiasaan, kekuatan diri dan kelemahan, bakat, dan minat serta penyalurannya.

2) Pengentasan kelemahan diri dan pengembangan kekuatan diri.

3) Mengembangkan kemampuan berkomunikasi, menerima dan menyampaikan pendapat, bertingkah laku sosial, baik dirumah, sekolah, dan masyarakat.

\section{Dasftar Pustaka}

A.Hallen . Bimbingan dan Konseling. Quantum Teaching. 2005. Jakarta

Masdudi. 2015. Bimbingan dan Konseling Perspektif Sekolah. Nurjati Press: Cirebon.

Prayitno, Erman Amti. Dasar-dasar bimbingan dan konseling. Rineka Cipta. 2004. Jakarta

Prayitno. Layanan Konseling (Layanan L.1-L.9). 2004

Suhertina. 2014. Dasar-Dasar Bimbingan dan Konseling. Pekanbaru: CV. Mutiara Pesisir Sumatra

Syahriman. 2012. Wawasan Dasar Bimbingan dan Konseling. Bengkulu. 